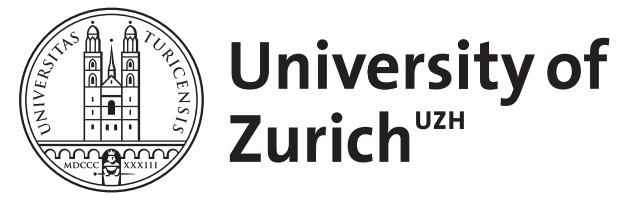

\title{
Intrauterine rubella virus infection despite expected maternal immunity
}

\author{
Bossart, W ; Nadal, D
}

DOI: https://doi.org/10.1007/bf01708631

Posted at the Zurich Open Repository and Archive, University of Zurich

ZORA URL: https://doi.org/10.5167/uzh-155672

Journal Article

Published Version

Originally published at:

Bossart, W; Nadal, D (1998). Intrauterine rubella virus infection despite expected maternal immunity.

European Journal of Clinical Microbiology Infectious Diseases, 17(8):597-599.

DOI: https://doi.org/10.1007/bf01708631 
Table 1 Clinical and laboratory findings in patients with HIV infection and periungual erythema

\begin{tabular}{|c|c|c|c|c|c|c|c|c|}
\hline $\begin{array}{l}\text { Patient } \\
\text { no. }\end{array}$ & $\begin{array}{l}\text { Age in } \\
\text { years/sex }\end{array}$ & $\begin{array}{l}\text { Focus of } \\
\text { infection }\end{array}$ & $>1 x^{*}$ & $\begin{array}{l}\text { Mode of } \\
\text { transmission }\end{array}$ & $\begin{array}{l}\text { CDC } \\
\text { classi- } \\
\text { fication }\end{array}$ & $\begin{array}{l}\mathrm{CD} 4+\mathrm{T} \\
\text { cell count } \\
\text { in } \mu \mathrm{l}\end{array}$ & $\begin{array}{l}\text { HIV viral } \\
\text { load } \\
\text { (copies } / \mathrm{ml} \text { ) }\end{array}$ & $\begin{array}{l}\text { HCV } \\
\text { anti- } \\
\text { bodies }\end{array}$ \\
\hline 1 & $36 / \mathrm{m}$ & $\mathrm{F} / \mathrm{T} / \mathrm{P}$ & yes & iv & $\mathrm{C} 3$ & 160 & 23993 & pos \\
\hline 2 & $40 / \mathrm{m}$ & $\mathrm{T}$ & no & iv & B1 & 608 & 3847 & pos \\
\hline 3 & $35 / f$ & $\mathrm{~T}$ & no & iv & B3 & 190 & 793404 & pos \\
\hline 4 & $32 / \mathrm{m}$ & $\mathrm{T} / \mathrm{P}$ & no & iv/msm & $\mathrm{C} 3$ & 100 & 413 & pos \\
\hline 5 & $31 / \mathrm{f}$ & $\mathrm{F} / \mathrm{P}$ & yes & iv & $\mathrm{C} 3$ & 157 & 750000 & pos \\
\hline 6 & $30 / \mathrm{f}$ & $\mathrm{T} / \mathrm{P}$ & yes & iv & B2 & 374 & 766 & pos \\
\hline 7 & $38 / \mathrm{m}$ & $\mathrm{F}$ & yes & iv & B3 & 260 & $<244$ & pos \\
\hline 8 & $33 / \mathrm{m}$ & $\mathrm{F}$ & no & $\mathrm{msm}$ & $\mathrm{A} 2$ & 370 & 38515 & neg \\
\hline 9 & $39 / \mathrm{m}$ & $\mathrm{T}$ & no & iv & B3 & 45 & 122085 & nd \\
\hline 10 & $38 / \mathrm{f}$ & $\mathrm{F}$ & yes & iv & $\mathrm{C} 3$ & 57 & 15474 & prob \\
\hline 11 & $58 / \mathrm{m}$ & $\mathrm{T} / \mathrm{P}$ & no & bi & $\mathrm{C} 3$ & 5 & 169254 & neg \\
\hline 12 & $33 / \mathrm{m}$ & $\mathrm{T}$ & no & iv & $\mathrm{C} 3$ & 30 & 40271 & pos \\
\hline 13 & $34 / \mathrm{m}$ & $\mathrm{F}$ & no & iv & $\mathrm{C} 2$ & 260 & $<274$ & pos \\
\hline 14 & $31 / \mathrm{m}$ & $\mathrm{T} / \mathrm{P}$ & yes & iv & B3 & 119 & $<418$ & pos \\
\hline 15 & $35 / \mathrm{m}$ & $\mathrm{T}$ & yes & hetero & B3 & 170 & 206167 & neg \\
\hline 16 & $29 / \mathrm{f}$ & $\mathrm{F} / \mathrm{P}$ & yes & iv & B2 & 310 & na & na \\
\hline 17 & $56 / \mathrm{m}$ & $\mathrm{F}$ & no & $\mathrm{msm}$ & B2 & 270 & nd & neg \\
\hline 18 & $57 / \mathrm{m}$ & $\mathrm{T}$ & no & $\mathrm{msm}$ & $\mathrm{C} 3$ & 20 & 45060 & neg \\
\hline 19 & $28 / \mathrm{f}$ & $\mathrm{F}$ & no & iv & A1 & 851 & 1329 & pos \\
\hline 20 & $33 / \mathrm{m}$ & $\mathrm{F} / \mathrm{P}$ & no & iv & $\mathrm{C} 3$ & 135 & 165616 & na \\
\hline 21 & $36 / \mathrm{f}$ & $\mathrm{F} / \mathrm{T} / \mathrm{P}$ & yes & iv & C3 & 95 & 4467 & pos \\
\hline
\end{tabular}

* Diagnosis was established in more than one consultation

bi, bisexual; CDC, Centers for Disease Control; F, fingers; HCV, hepatitis C virus; hetero, heterosexual intercourse; iv, intravenous drug abuse; $m s m$, men having sex with men; na, not available; nd, not done; neg, negative; $\mathrm{P}$, palmar erythema; pos, positive; prob, probable; $\mathrm{T}$, toes

these three patients periungual erythema was seen only once, and in two of them it disappeared before the next follow-up visit. However, it is also possible that the serological test for HCV was falsely negative [6]. All patients described by Pechère et al. [2] were intravenous drug users or alcohol abusers. Interestingly, all of our patients who were intravenous drug users had positive serological tests for $\mathrm{HCV}$. There was no correlation between diagnosis of the periungual erythema and the activity of the HIV infection expressed by the actual viral load.

We conclude that periungual erythema in HIV-infected patients is most often associated with $\mathrm{HCV}$ infection with or without concomitant activity and non-virusinduced chronic liver disease. Other associations are suggested, especially in transient periungual erythema. Possibly, non-organ-specific autoantibodies in HIV infection [7] play a role in the pathogenesis of periungual erythema, reflecting the large spectrum of antibodies found in HIV-infected patients.

\section{References}

1. Itin PH, Gilli L, Nüesch R, Courvoisier S, Battegay M, Rufli T, Gasser P: Erythema of the proximal nail fold - a further cutaneous clue to HIV infection? Dermatology (1995) 191:176

2. Pechère $M$, Krischer $J$, Rosay $A$, Hirschel $B$, Saurat JH: Red fingers syndrome in patients with HIV and hepatitis C infection. Lancet (1996) 348:196-197

3. Battegay M, Itin PH: Red fingers syndrome in HIV patients. Lancet (1996) 348:763
4. Itin PH, Gilli L, Nüesch R, Courvoisier S, Battegay M, Rufli T, Gasser P: Erythema of the proximal nail fold in HIV-infected patients. Journal of the American Academy of Dermatology (1996) 35:631-633

5. Levey JM, Bjornsson B, Banner B, Kuhns M, Malhotra R, Whitman N, Romain PL, Cropley TG, Bonkovsky HL: Mixed cryoglobulinemia in chronic hepatitis $\mathrm{C}$ infection. Medicine (1994) 73:53-67

6. Sugitani M, Inchauspe G, Shindo M, Prince AM: Sensitivity of serological assays to identify blood donors with hepatitis $\mathrm{C}$ viraemia. Lancet (1992) 339:1018-1019

7. Muller S, Richalet $P$, Laurent-Crawford A, Barakat S, Riviere Y, Porrot F, Chamaret S, Briand JP, Montagnier L, Hovanessian A: Autoantibodies typical of non-organ-specific autoimmune diseases in HIV-seropositive patients. AIDS (1992) $6: 933-942$

\section{Intrauterine Rubella Virus Infection Despite Expected Maternal Immunity}

\author{
W. Bossart, D. Nadal
}

Screening for immunity against the rubella virus is an essential part of the prenatal care of pregnant women.

W. Bossart (区)

Institute of Medical Virology, University of Zurich,

Gloriastrasse 30, CH-8028 Zurich, Switzerland

D. Nadal

University Children's Hospital, Infectious Disease Unit,

University of Zurich, Steinwiesstrasse 75, CH-8032 Zurich,

Switzerland 
Table 1 Rubella-specific antibodies in the sera of the mother and her infant at different points in time

\begin{tabular}{|c|c|c|c|c|c|c|}
\hline \multirow[t]{2}{*}{ Time antibody test performed } & \multicolumn{3}{|l|}{ Mother } & \multicolumn{3}{|l|}{ Infant } \\
\hline & $\begin{array}{l}\operatorname{IgG} \\
(\mathrm{IU} / \mathrm{ml})\end{array}$ & $\operatorname{IgM}$ & $\mathrm{NT}^{\mathrm{a}}$ & $\begin{array}{l}\text { IgG } \\
(\mathrm{IU} / \mathrm{ml})\end{array}$ & $\operatorname{lgM}$ & NT \\
\hline First trimester of pregnancy & 195 & neg & 0 & n.d. & n.d. & n.d. \\
\hline At birth/delivery & 149 & neg & 0 & 171 & neg & 0 \\
\hline 3 months after birth & n.d. & n.d. & n.d. & $43^{b}$ & neg & $+t^{b}$ \\
\hline Before vaccination $^{c}$ & 136 & neg & ++ & 0 & neg & 0 \\
\hline 1 month after vaccination & 188 & neg & ++ & 98 & pos & ++ \\
\hline
\end{tabular}

a Neutralisation of rubella virus by serum diluted $1: 10$

${ }^{b}$ The child received intravenous immunoglobulins on the second day of life

${ }^{\circ}$ Mother and infant were vaccinated with live attenuated rubella virus 15 months after birth

n.d., not done; neg, negative; pos, positive; NT, neutralising antibodies; 0 , no neutralisation; + , weak neutralisation; ++ , strong neutralisation
Infection of pregnant women who were expected to be immune to rubella, with subsequent transmission of the pathogen to the foetus, has been reported [1]. We present a case of rubella infection in the full-term infant of a seropositive mother who lacked neutralising antibodies. Our observation challenges immunity screening on the basis of mere antibody quantitation.

A newborn girl was referred to the University Children's Hospital, Zurich on the first day of life because she had petechiae, severe thrombocytopenia $\left(13 \times 10^{9} / 1\right)$, and ventricular extrasystoles. Neonatal alloimmune thrombocytopenia was diagnosed. Thrombocytes and immunoglobulins were infused. The infant's cardiac arrhythmia resolved spontaneously within 2 days.

Rubella virus was isolated in shell vial cultures of RK13 rabbit kidney cells from throat swabs and urine collected on the infant's second day of life. Throat swab and urine samples were tested in parallel and in duplicate; no other samples tested positive for rubella virus the same working day. The immunofluorescence assay was validated by an inactivated positive control slide; no rubella virus was actively cultured in the laboratory during the relevant time period. Thus, mixing of the clinical samples is unlikely, and the possibility of laboratory contamination can be ruled out. The child showed no clinical or radiological signs of congenital rubella and developed normally. Viral cultures performed 3 weeks after birth were negative.

Rubella antibody determinations were performed initially by an external laboratory (IMX system; Abbott; Switzerland) and later by our own laboratories (Access system; Sanofi Pasteur Diagnostics, Switzerland). The sensitivity and specificity of the appropriate IgG tests were $99.7 \%$ and $98.9 \%$, respectively, for the IMX system and $99.37 \%$ and $99.37 \%$, respectively, for the Access system. For IgM confirmatory tests, the Sorin $\mu$-capture enzyme immunoassay (EIA) (Sorin Biomedica; Italy) was used (sensitivity, $99.7 \%$; specificity, $99.9 \%$ ). The mother had not been immunised but was shown to be seropositive for rubella virus by both laboratories. Sera collected from the mother during the first trimester of pregnancy and at delivery and from the infant on her second day of life prior to immmunoglobulin infusion contained rubella-specific $\operatorname{IgG}$ and no specific IgM (Table 1). However, none of the sera contained neutralising antibodies, as demonstrated in vitro [2] using the Thomas laboratory strain of rubella virus. In contrast, the child's serum collected at age 3 months showed neutralising activity, which apparently originated from the infused immunoglobulins since the titre of specific IgG had dropped markedly. Investigation of the immune response to live attenuated rubella vaccine (strain Wistar-RA 27/3) 15 months after birth revealed a slight increase of specific IgG levels in the mother and seroconversion for $\operatorname{IgM}$ and $\operatorname{IgG}$ in the child. Moreover, the maternal pre-immunisation serum and the post-immunisation sera of both mother and child strongly neutralised rubella virus.

In this case the rubella infection would have gone unrecognised if neonatal alloimmune thrombocytopenia with petechiae had not necessitated tests for intrauterine infection. Isolation of rubella virus from two different body sites of the 2-day-old infant suggests an intrauterine infection, which seems to have been facilitated by the absence of maternal neutralising antibodies and to have occurred shortly before birth. Moreover, this infection seems to have resulted in the subsequent appearance of neutralising antibodies in the mother. The infused immunoglobulins may have contributed to clearing the virus and impeding a serologic response in the child $[3,4]$.

In most countries immunity to rubella virus is determined solely on the basis of quantitative IgG antibody determination. However, in a few countries such as Germany, $\operatorname{IgG}$ quantitation is combined with haemagglutination inhibition tests, which may correlate with neutralising antibodies [5]. As shown by our case, a functional test for determining the appropriate neutralising capacity of rubella antibodies has merit. 
However, the addition of a neutralisation test to the antibody quantitation test to determine resistance to rubella in pregnant women would result in a considerable increase in testing and costs. Because the haemagglutination inhibition test is less demanding with respect to time and technical skills, it offers a more acceptable cost-to-benefit ratio than the classical neutralisation test. Additional studies are required to estimate the proportion of women who have EIA-positive, non-neutralising antibodies. This proportion may depend on the rates of natural infection and vaccination and, thus, may vary from country to country.

\section{References}

1. Robinson J, Lemay M, Vaudry WL: Congenital rubella after anticipated maternal immunity: two cases and a review of the literature. Pediatric Infectious Disease Journal (1994) $13: 812-815$

2. Schmidt NJ: Cell culture technics for diagnostic virology. In: Diagnostic procedures for viral, rickettsial, and chlamydial infections. Lennette EH, Schmidt NJ (eds): American Public Health Association, Washington DC (1979): pp. 65

3. Buckley RH, Schiff RI. The use of intravenous immune globulin in immunodeficiency diseases. New England Journal of Medicine (1991) 325:110-117

4. Dwyer JM: Manipulating the immune system with immune globulin. New England Journal of Medicine (1992) 326:107-116

5. Braun R, Hornig C, Sann G, Doerr HW: Comparison of different methods for assessment of rubella infection and immunity. Zentralblatt für Bakteriologie, Mikrobiologie und Hygiene (A) (1982) 252:431-437 